\title{
Effect of Counter-Ion Charge and Hydration on Poly $(3,4-$ ethylenedioxythiophene) (PEDOT) Studied with X-ray Photoelectron Spectroscopy
}

\author{
S.A. Spanninga ${ }^{1}$, Z. Chen ${ }^{1,2}$, and D.C. Martin ${ }^{1,3,4}$
}

1 Macromolecular Science and Engineering Center, University of Michigan, Ann Arbor, MI 48109

2 Department of Chemistry, University of Michigan, Ann Arbor, MI 48109

3 Materials Science and Engineering, University of Delaware, Newark, Delaware, 19716

4 Department of Materials Science and Engineering, Ann Arbor, MI 48109

Poly(3,4-ethylenedioxythiophene) (PEDOT), is a highly conductive ( 300 S/cm) [1], $\pi$ conjugated polymer that can be synthesized by either oxidative chemical, organic vapor, or by electrochemical polymerization. PEDOT applications include anti-static coatings and organic light emitting devices [1], but more recent studies have taken advantage of both the electronic and ionic conductivity for the use of PEDOT as a biological tissue interfacing agent $[2,3]$.

While previous work focused on how different counter-ions affected both on the polymer surface morphology and electrical properties of the PEDOT polymer film [4,5], the motivation driving this research was to deduce whether anion hydration was indeed the driving force dictating PEDOT counter-ion incorporation. X-ray photoelectron spectroscopy (XPS) was used to deduce the respective PEDOT film's chemical composition.

In order to deduce whether the anionic hydration trend, based upon the Hofmeister Series [6-8], coincides with PEDOT counter-ion affinity, a systematic study of 3,4-ethylenedioxythiophene with various differently hydrated anion mixtures (most to least hydrated anions) were mixed and a electrochemically polymerized PEDOT film was deposited. The anions used were: (1) $\mathrm{C}_{6} \mathrm{H}_{5} \mathrm{O}_{7}{ }^{-3}$, (2) $\mathrm{CO}_{3}{ }^{-2}$, (3) $\mathrm{S}_{2} \mathrm{O}_{3}{ }^{-2}$, (4) $\mathrm{C}_{2} \mathrm{H}_{3} \mathrm{O}_{2}^{-}$, (5) $\mathrm{HPO}_{4}{ }^{-2}$, (6) $\mathrm{H}_{2} \mathrm{PO}_{4}^{-}$, (7) $\mathrm{Cl}^{-}$, and (8) $\mathrm{Br}^{-}$followed by either $\mathrm{NO}_{3}{ }^{-}$or $\mathrm{ClO}_{4}^{-}$additions. The $\mathrm{C} 1 \mathrm{~s}$ and $\mathrm{S} 2 \mathrm{p}$ characteristic region results are shown in Figure 1 and 2 respectively.

The $\mathrm{C} 1 \mathrm{~s}$ region, before the addition of $\mathrm{Na}_{2} \mathrm{~S}_{2} \mathrm{O}_{3}$ to the mixture, was dominated by COO- $(\sim 289 \mathrm{eV})$. Once the addition of $\mathrm{Na}_{2} \mathrm{~S}_{2} \mathrm{O}_{3}$ was made, the PEDOT ${ }^{+} \mathrm{S}_{2} \mathrm{O}_{3}{ }^{-2}$ low, broad $\mathrm{S} 2 \mathrm{p}$ spin-split doublet appeared and displayed dominance over all the other anions regardless of their anionic hydration state. Lack of PEDOT ${ }^{+} \mathrm{CO}_{3}^{-2}(\sim 289 \mathrm{eV})$ and $\mathrm{PEDOT}^{+} \mathrm{COO}^{-}(\sim 289 \mathrm{eV})$ signals in $\mathrm{C} 1 \mathrm{~s}$, phosphate signal in the $\mathrm{P} 2 \mathrm{p}$ (not shown), $\mathrm{ClO}_{4}{ }^{-}$and $\mathrm{Cl}^{-}$signals in the $\mathrm{Cl} 2 \mathrm{p}$ (not shown) [10], $\mathrm{Br}^{-}$signal in the $\mathrm{Br} 3 \mathrm{~d}$ (not shown), and $\mathrm{NO}_{3}{ }^{-}$in the $\mathrm{N} \mathrm{1s}$ (not shown), eliminates the possibility of the other anions, $\mathrm{CaCO}_{3}, \mathrm{NaC}_{2} \mathrm{H}_{3} \mathrm{O}_{2}, \mathrm{Na}_{2} \mathrm{HPO}_{4}, \mathrm{NaH}_{2} \mathrm{PO}_{4}, \mathrm{NaCl}, \mathrm{LiBr}, \mathrm{NaNO}_{3}$, and $\mathrm{LiClO}_{4}$, as acting as PEDOT counter-ions.

\section{References}

[1] L. Groenendaal et. al., Adv. Mater. 12 (2000) 481.

[2] D.H. Kim et al., Adv. Funct. Mater. 17 (2007) 79.

[3] S.M. Richardson-Burns et al., Biomaterials 28 (2007) 1539.

[4] S.A. Spanninga et al., J. Phys. Chem. C 113 (2009) 5585.

[5] J. Yang et al., J. Biomater. Sci. Polymer Edn., 18 (2007) 1075. 
[6] W. Kunz et al., Curr. Opin. Colloid Interface Sci. 9 (2004) 19.

[7] Y. Marcus, J. Soln. Chem. 23 (1994) 831.

[8] H.D.B. Jenkins et al., Chem. Rev. 95 (1995) 2695.



FIG. 1. Characteristic C 1s Region

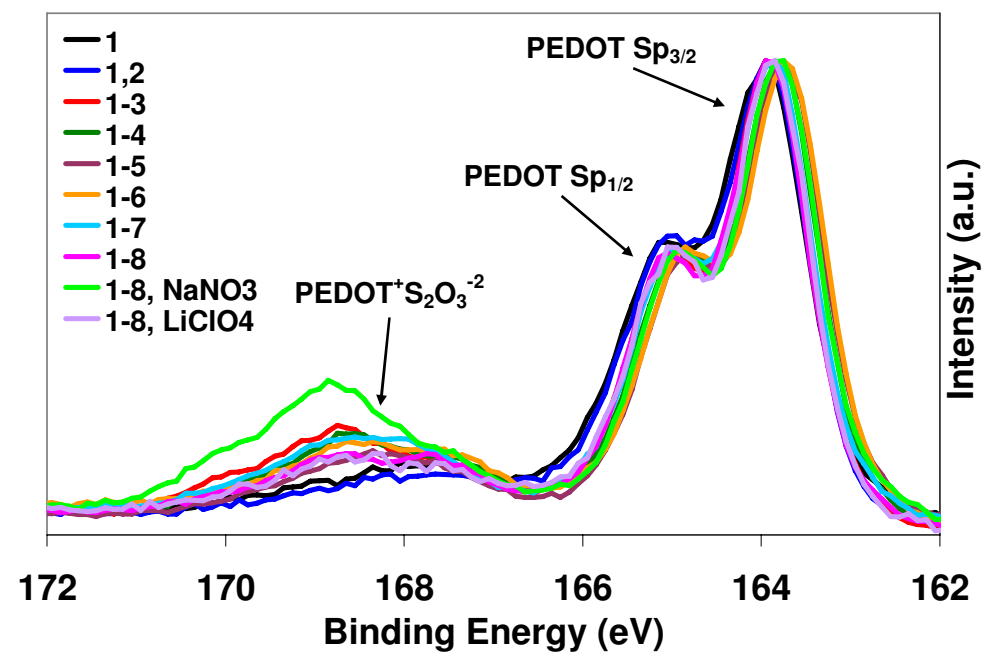

FIG. 2. Characteristic S 2p Region 